\title{
A study on impact of select factors on the price of Gold
}

\author{
Dr. Sindhu* \\ Associate Professor, School of Management Studies, Jawaharlal Nehru Technological University Hyderabad. \\ Kukatpally, Hyderabad -500 085, India.
}

\begin{abstract}
The investors always look for the various investment avenues which increase their risk-adjusted returns and add diversification. Since ages, gold is preferred as the one of the major investment option especially by the Indian investors. The prices of the gold are increasing and the price of the gold is affected by the various factors. This paper is basically focused on the factors like exchange rate of US dollar with INR, Crude oil prices, repo rate and inflation rate. Each of the factors is studied with the gold prices. The relationship between the factor and the gold prices is emphasized in this paper. There exists an inverse relation between the US\$ and gold prices. The crude oil prices have an impact on the gold prices. Gold prices and repo rates are interdependent. Gold prices and inflation rates are also dependent and positively correlated.
\end{abstract}

Key Words: Crude oil prices, Diversification, exchange rate of USD and INR, Gold Prices, Inflation, Investment, repo rate.

\section{Introduction}

Diversified Portfolios which contain assets such as private equity, hedge funds, real estate and commodities can be enhanced by adding a discrete allocation to gold as a foundation. Investors are looking to increase their risk-adjusted returns and add diversification. However, gold produces benefits that separate it from other investments. It is not only an ideal source of diversification for an investor's portfolio, but also provides a foundation which investors rely on to manage risk and preserve capital more efficiently, especially in times of financial turmoil when stability is needed the most. Moreover, an allocation to gold provides investors with the confidence to invest in a wider range of strategies including alternative assets.

Sherman (1983) in his study on a gold pricing model has concluded that gold price has a significant positive relationship with unexpected inflation. Similar study is carried out by Moore (1990) that the gold price movements are predicted by a leading indicator of inflation. A research study by Larson \& McQueen(1995) conclude that there is coefficient of unexpected inflation for gold price is significant. Sadorsky (1999) to explore the correlation among three - month US Treasury interest rates, S \& P 500 stock returns and oil prices.

Adrangi et al. (2003) conclude that gold has a positive relationship with expected inflation; there exists no relationship with unexpected inflation. Ratanapakorn and Sharma (2007) studied the long-term and shortterm relationships among the US stock price index(S\&P 500) and macroeconomic variables during a study period from $1^{\text {st }}$ quarter 1975 to $4^{\text {th }}$ quarter 1998 . The stock price index and long-term interest rates are negatively correlated as per the empirical study. Blose (2010) has concluded that unexpected changes in CPI do not affect gold spot prices and investors cannot determine market inflation expectations by examining the price of gold.

Researchers have made an attempt to explore the reasons of investment in gold. An analytical research work has been carried out by Sashikant Singh in Dalal Street Journal on how investing in Gold ETF's has started gaining popularity in recent times. The analysis is based on the various options for investing in gold such bars, coins, ETF's. It has been observed that investing in gold

ETF's is less risky and less cumbersome than the other means available in investing in gold. He has concluded that investing in gold ETF's are becoming more popular and Sachs Gold ETF's and Kotak Gold ETF's looks better keeping in mind the liquidity available in it.

The research work carried out by Devdutt Pattanaik in his research paper "Sacred Gold" published by World Gold Council mainly focuses on the mythological and cultural significance of

gold in India. According to him Indians love gold and this has been explained logically and culturally. Logically, gold is a tangible investment, unlike shares and bonds; a portable investment, unlike property and a beautiful ornament, one that can be worn daily on the body as jewellery. But the same can be said of diamonds and other precious metals.

Kannan carried out an "econometric analysis" for knowing the Indian gold demand from 1980-2009 and the key drivers for this gold demand published by the World Gold Council. He has

observed that for the higher income level group's platinum is a substitute for gold but for the majority gold is "a way of life". The value of gold stems from jewellery to a major vehicle of wealth accumulation by the low and middle-income households in rural and urban areas. The key drivers for the gold demand were real income level of the population, expectation of higher gold price, exchange rates, as an alternative instrument of saving, gold as an equity security, constrained supply conditions, the relationship between savings and uncertainty. Empirical 
studies reveal that gold demand is not only price sensitive but also affected by macro economic variables and financial variables.

It has been understood from above that one of the factors affecting gold price is also exchange rates. This area was further studied by Capie et. al(2005) conclude Gold as a Hedge against the US Dollar. Much focus was drawn on the relationship between gold price and US Dollar. A statistical approach was adopted to study the behaviour of gold with respect to Dollar value. A variety of statistical tools were applied to explore the relationship between gold and the exchange rates of various currencies against the US dollar. The relationship was examined over the whole periods of years from 1971 to 2002, with particular attention paid to the hedging properties of gold in episodes of economic or political turmoil. The US dollar gold price was found to move in opposition to the US dollar and the movement was especially contemporaneous. For each exchange rate considered, a typical weekly movement against the dollar generated a movement in the gold price. The overall conclusion of this study is that gold is indeed a hedge against fluctuations of the US Dollar on the foreign exchanges.

\section{Need and objectives of the Study:}

There are a number of distinctive qualities that separate gold from the rest of the commodities, such as the U.S. dollar is weakening, Inflation fears, Emergence of China and India, Supply constraints, Geopolitical instability. But gold is viewed as a safe haven during times of political or economic calamity.

\section{Objectives of the study:}

- To analyze the different factors which affect the price of gold.

- To study and analyze the impact of exchange rate of USD with INR on gold prices.

- To study and analyze the impact of Prices of crude oil on the gold prices.

- To study and analyze the impact of repo rate on the gold price.

- To study and analyze the impact of Inflation on the gold prices

\section{Research Methodology:}

For causal research to establish the quantitative relationship between prices of gold and other factors (daily prices of gold and other factors) were collected from the various secondary sources like newspapers, internet, magazines, books, journals were referred to understand the relationship between price movements of gold and other factors. The major data sources are WGC(World Gold Council), Gem \& Jewellery Export Promotion Council (GJEPC), MMTC Ltd, State Trading Corporation(STC Ltd). In addition to usage of statistical packages the quantitative data was analyzed through regression etc. For the quantitative study, the period of five years is taken commencing from November 2006 to December 2011 is considered, during which daily prices of gold and other factors were taken into account.

\section{Hypotheses:}

1. Hypothesis Assumed $\left(\mathbf{H}_{\mathbf{0}}\right)$ : Gold Prices do not depend upon Dollar exchange rate.

2. Hypothesis Assumed $\left(\mathbf{H}_{\mathbf{0}}\right)$ : Gold prices do not depend on crude oil prices.

3. Hypothesis Assumed $\left(\mathbf{H}_{0}\right)$ : The Repo rate does affect the gold prices.

4. Hypothesis Assumed $\left(\mathbf{H}_{\mathbf{0}}\right)$ : The Inflation rate doesn't affect the gold prices.

\section{Tools and techniques:}

A comparative analysis of various factors has been done on the various parameters like trend analysis, Standard Deviation, Regression, and correlation to make possible the tedious task of analysis of these factors. Further analyzing the factors will suggest the investors that whether it will be profitable for the investors to invest in gold or not.

\section{Data Analysis:}

The factors that impact the price of the gold is given below and also the changes in these factors on the gold price is studied.

- US Dollar,

- Crude oil Price

- Repo Rates

- Inflation Rates

The analysis of all these above mentioned factors is as follows:

\section{US DOLLAR:}

It is an important question that is there any correlation between gold prices and the value of US DOLLAR. Now the answer depends upon situation and changes with change in global economic scenario. Now 
there is an inverse relationship between gold prices and US Dollar. Before 1950 US \$ was also considered as the inflation hedge. But this is not true now. So in the past it can observe the positive correlation between gold prices and US \$. But now the relation is negative. US has a large debt (15 trillion $\$$ as on $16^{\text {th }}$ February, 2012) and also it pays more interest than it earns. So it creates a downward pressure on the Dollar and makes it weak. This creates an inverse relation.

As a tool of hedge now gold is demanded more than the US \$. When the price of gold depreciates the investors outside US will benefited because the dollar price of the gold will increase. Investor can shift away from the dollar denominated assets to gold. Past experiences also that gold has been used as a hedge against currency risk.

\section{Graph: 1 Gold price Vs US Dollar:}

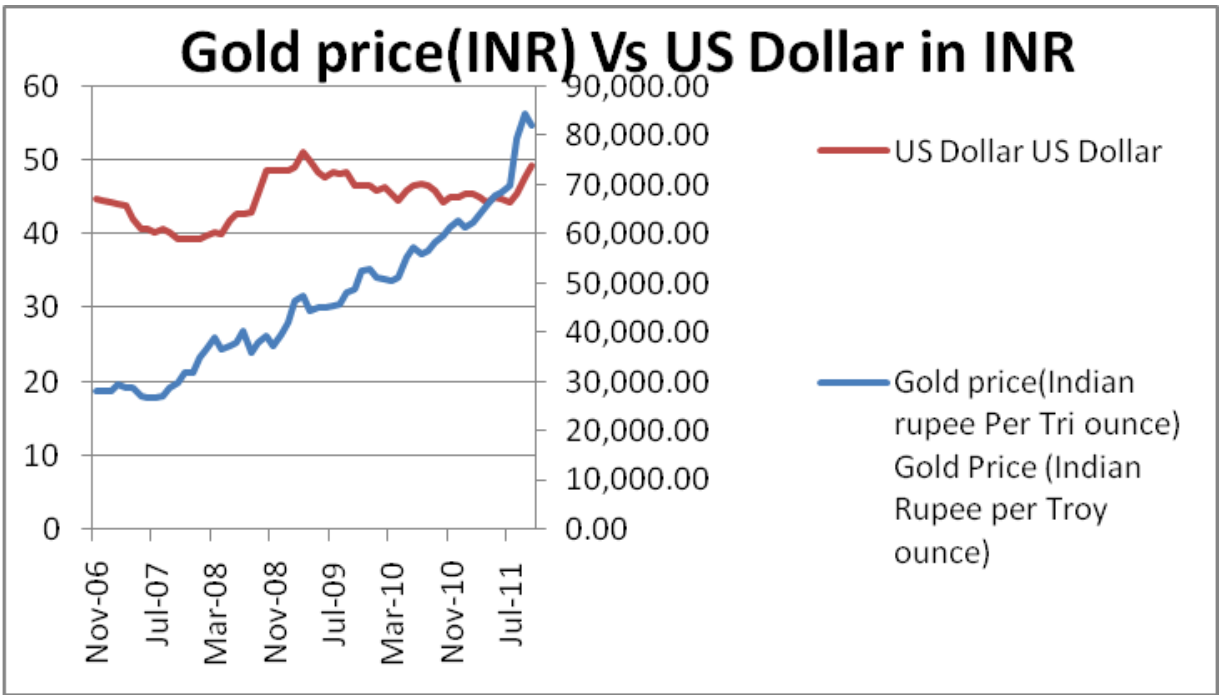

Graph2: Trend Analysis of USD Vs Gold Price:

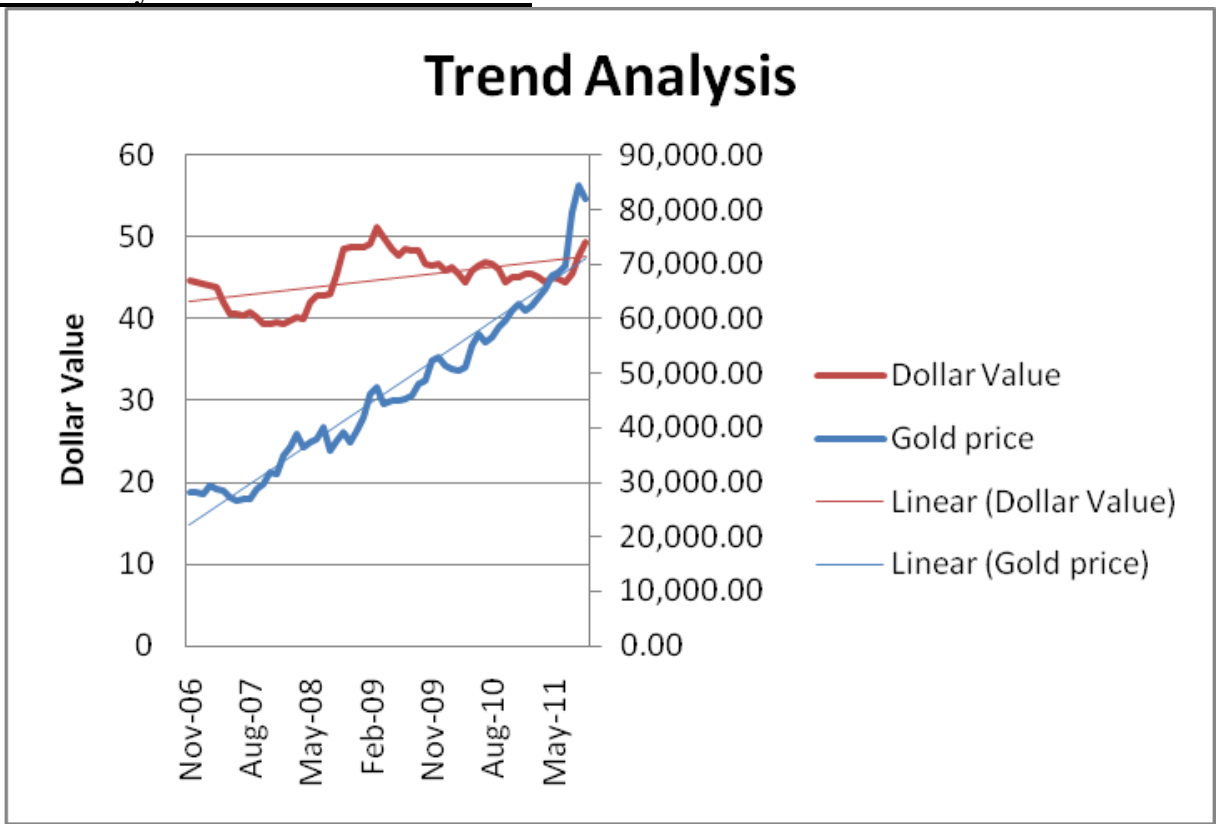

1. Hypothesis Assumed $\left(\mathbf{H}_{0}\right)$ : Gold Prices do not depend upon Dollar exchange rate.

\begin{tabular}{|c|c|}
\hline \multicolumn{2}{|c|}{ Regression Statistics } \\
\hline Multiple R & 0.477275 \\
\hline R Square & 0.227792 \\
\hline Adjusted R Square & 0.214478 \\
\hline Standard Error & 13292.35 \\
\hline Observations & 60 \\
\hline ANOVA
\end{tabular}




\begin{tabular}{|c|c|c|c|c|c|}
\hline & $\boldsymbol{d} \boldsymbol{f}$ & $\boldsymbol{S S}$ & $\boldsymbol{M S}$ & $\boldsymbol{F}$ & $\begin{array}{c}\text { Significance } \\
\boldsymbol{F}\end{array}$ \\
\hline Regression & 1 & $3.02 \mathrm{E}+09$ & $3.02 \mathrm{E}+09$ & 17.10929 & 0.000115 \\
\hline Residual & 58 & $1.02 \mathrm{E}+10$ & $1.77 \mathrm{E}+08$ & & \\
\hline Total & 59 & $1.33 \mathrm{E}+10$ & & & \\
\hline
\end{tabular}

\begin{tabular}{|c|c|c|c|c|c|c|c|c|}
\hline & Coefficients & $\begin{array}{c}\text { Standard } \\
\text { Error }\end{array}$ & $\boldsymbol{t}$ Stat & P-value & $\begin{array}{c}\text { Lower } \\
\mathbf{9 5 \%}\end{array}$ & $\begin{array}{c}\text { Upper } \\
\mathbf{9 5 \%}\end{array}$ & $\begin{array}{c}\text { Lower } \\
\mathbf{9 5 . 0 \%}\end{array}$ & $\begin{array}{c}\text { Upper } \\
\mathbf{9 5 . 0 \%}\end{array}$ \\
\hline $\begin{array}{c}\text { Intercept } \\
\mathbf{X} \\
\begin{array}{c}\text { Variable } \\
\mathbf{1}\end{array}\end{array}$ & -55386.6 & 24714.96 & -2.24102 & 0.028868 & -104859 & -5914.26 & -104859 & -5914.26 \\
& 2274.4 & 549.8584 & 4.136337 & 0.000115 & 1173.739 & 3375.061 & 1173.739 & 3375.061 \\
\hline
\end{tabular}

Tabulated $\mathrm{z}$-value $=3.856547$

Significant correlation with $\mathrm{R}=0.477275$. Approximately $22 \%$ of variation in gold prices accounted for with US Dollar value. Significant linear regression with $\mathrm{p}$ value $=0.000115$.

Regression Equation is $-\mathrm{Y}=22274.4 \mathrm{X}-55386.6$

Here the multiple $\mathrm{R}$ value is 0.477 which shows that there is significant correlation between the US dollar and the gold prices. This tells us that the current scenario of the US dollar does affect the gold prices. This $\mathrm{R}$ value is closer to 0.5 which makes it more significant. Also the value of $\mathrm{R}$ square is 0.227 which shows the extent to which the US Dollar value affects the gold prices. But from t value which is more than the tabulated value (hypothesis is accepted) it can predict that there is a relation between US $\$$ and gold prices. The $-v e$ intercept of $\mathrm{t}$ value as well as -ve intercept of regression equation shows the inverse relation between the US\$ and gold prices.

Therefore the hypothesis is rejected that gold prices do not depend upon the US dollar.

\section{CRUDE OIL:}

The crude oil is one of the factors for inflation. As the prices of crude oil increases, economy always falls into a recession there is upward pressure on inflation. In order to hedge against the inflation people invest in gold. So it can say that there is a relationship between gold and crude oil prices. It will be clearer from the following discussion.

Gold has almost always been the most-highly-sought-after universal store of wealth and the gold is the king of all the currencies. The demand for crude oil is in elastic. Now paper currencies lose their purchasing power with time but this doesn't happen with the gold. So during inflationary period when other currencies lose their value more gold can be purchased with gold due to its purchasing power stability. So during high crude oil prices, high inflation, and declining equity market gold can be stored to hedge the inflation.

\section{Graph 3: Trend Analysis for Gold Price and Crude oil Price:}

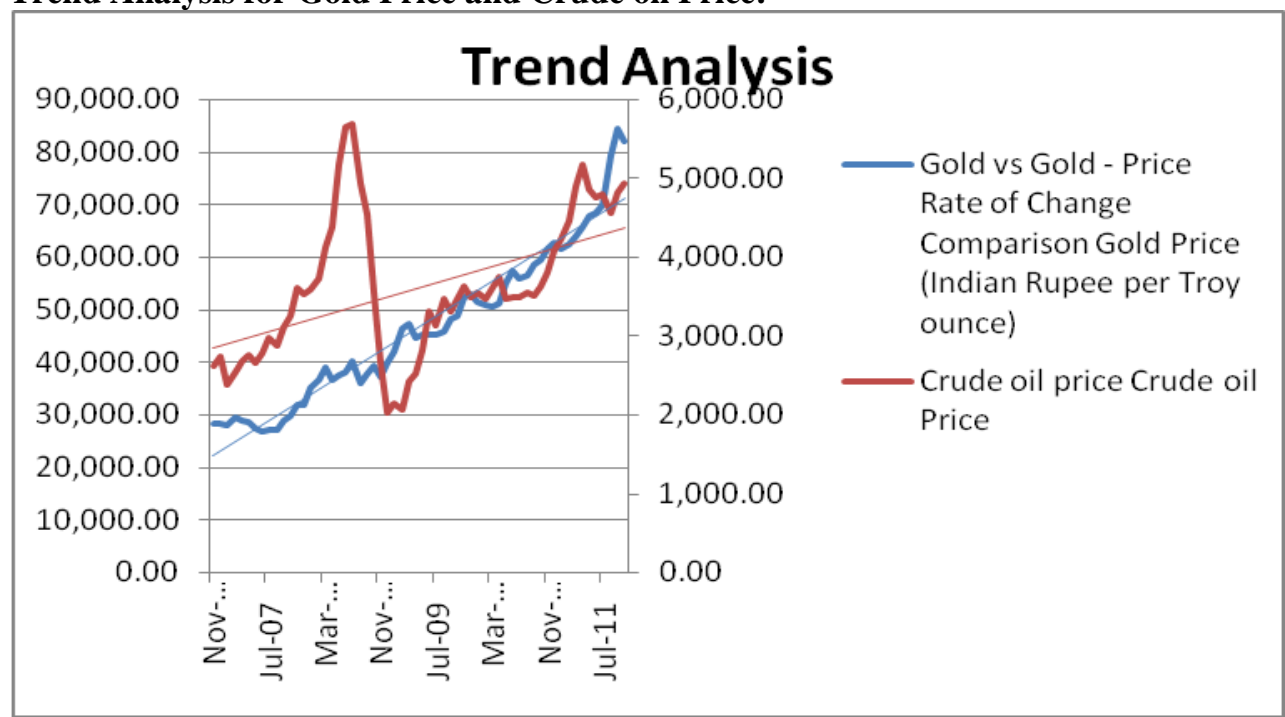

Hypothesis Assumed $\left(\mathbf{H}_{0}\right)$ : Gold prices do not depend on crude oil prices. 


\begin{tabular}{|c|c|}
\hline \multicolumn{2}{|c|}{ Regression Statistics } \\
\hline Multiple R & 0.520163 \\
\hline R Square & 0.27057 \\
\hline $\begin{array}{c}\text { Adjusted R } \\
\text { Square }\end{array}$ & 0.257994 \\
\hline Standard Error & 12918.92 \\
\hline Observations & 60 \\
\hline
\end{tabular}

ANOVA

\begin{tabular}{|c|c|c|c|c|c|c|c|c|}
\hline & $d f$ & SS & $M S$ & $F$ & Significance $F$ & & & \\
\hline Regression & 1 & $3.59 \mathrm{E}+09$ & $3.59 \mathrm{E}+09$ & 21.51415 & $2.05 \mathrm{E}-05$ & & & \\
\hline Residual & 58 & $9.68 \mathrm{E}+09$ & $1.67 \mathrm{E}+08$ & & & & & \\
\hline \multirow[t]{2}{*}{ Total } & 59 & $1.33 \mathrm{E}+10$ & & & & & & \\
\hline & Coefficients & $\begin{array}{c}\text { Standard } \\
\text { Error }\end{array}$ & $t$ Stat & $P$-value & $\begin{array}{c}\text { Lower } \\
95 \%\end{array}$ & $\begin{array}{c}\text { Upper } \\
95 \%\end{array}$ & $\begin{array}{l}\text { Lower } \\
95.0 \%\end{array}$ & $\begin{array}{l}\text { Upper } \\
95.0 \%\end{array}$ \\
\hline Intercept & 15596.6 & 6888.278 & 2.264224 & 0.027315 & 1808.217 & 29384.99 & 1808.217 & 29384.99 \\
\hline $\begin{array}{c}\text { X Variable } \\
1\end{array}$ & 8.58237 & 1.850313 & 4.638335 & $2.05 \mathrm{E}-05$ & 4.878567 & 12.28617 & 4.878567 & 12.28617 \\
\hline
\end{tabular}

Tabulated $\mathrm{z}$ value $=4.259374$

Significant correlation with $\mathrm{r}=0.52$. Approximately $27 \%$ of variation in gold prices accounted for with crude oil. Significant linear regression with p value -0.0000205 .

Regression Equation- Y=8.58237X+15596.6

$\mathrm{R}$ is 0.52 which shows that there is correlation between predicted gold prices and Actual one but it is greater than 0.5 which shows that the correlation is significant. It can also be interpreted from the $\mathrm{R}$ square value which is 0.27 which shows significance correlation. By $\mathrm{R}$ square it can be said that variation in crude oil prices accounts for $27 \%$ (approx) for the variation in the prices in gold. Also the t value is (4.63) greater than the tabulated value (4.25) which shows that the null Hypothesis is rejected. Therefore it can be said that the crude oil prices do affect the prices of gold significantly. Here it is important to know that there is great impact of the current economic scenario. It can be analyzed from the graph and the table that there is more correlation in some time period.

\section{REPO RATE:}

Repo Rate is that rate at which the commercial banks borrow money from the RBI. It is a good measure to control inflation. When the repo rate will be high, the borrowing from the banks will be low which will actually reduce the purchasing power of the public. This will reduce the investment in gold and it will ultimately reduce the price the gold.

\section{Graph4: Gold Price Vs Repo rate:}

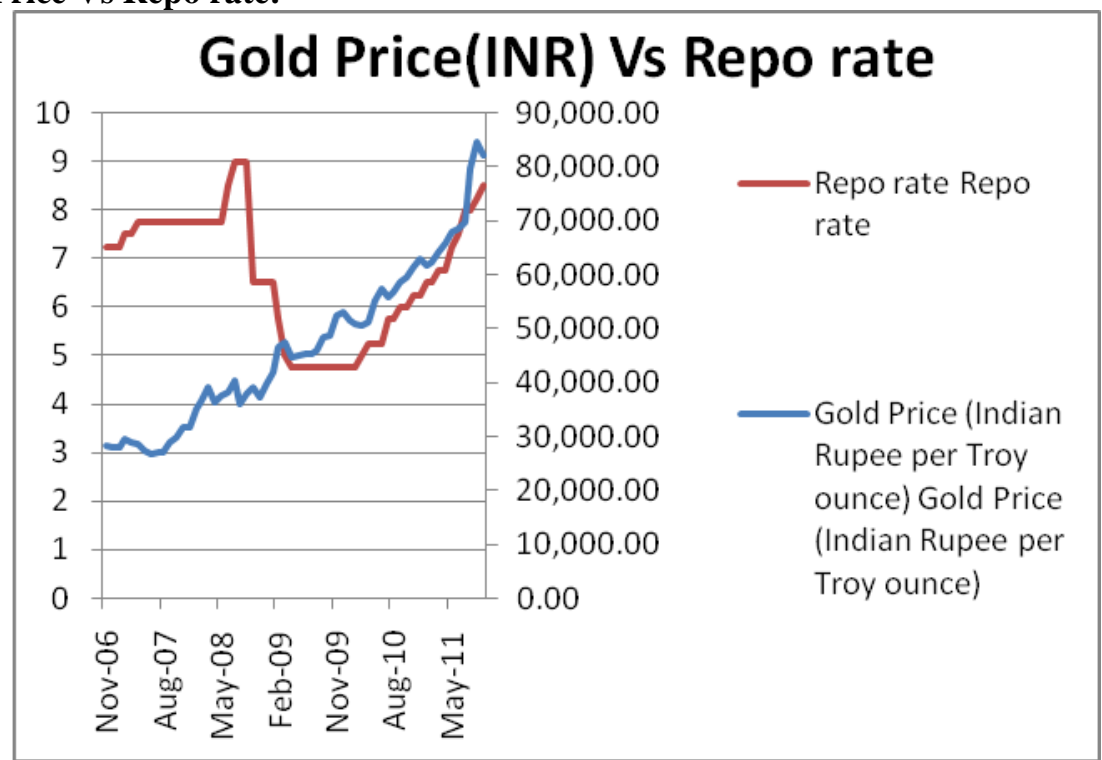

Graph5: Trend Analysis of Repo Rate and Gold price: 


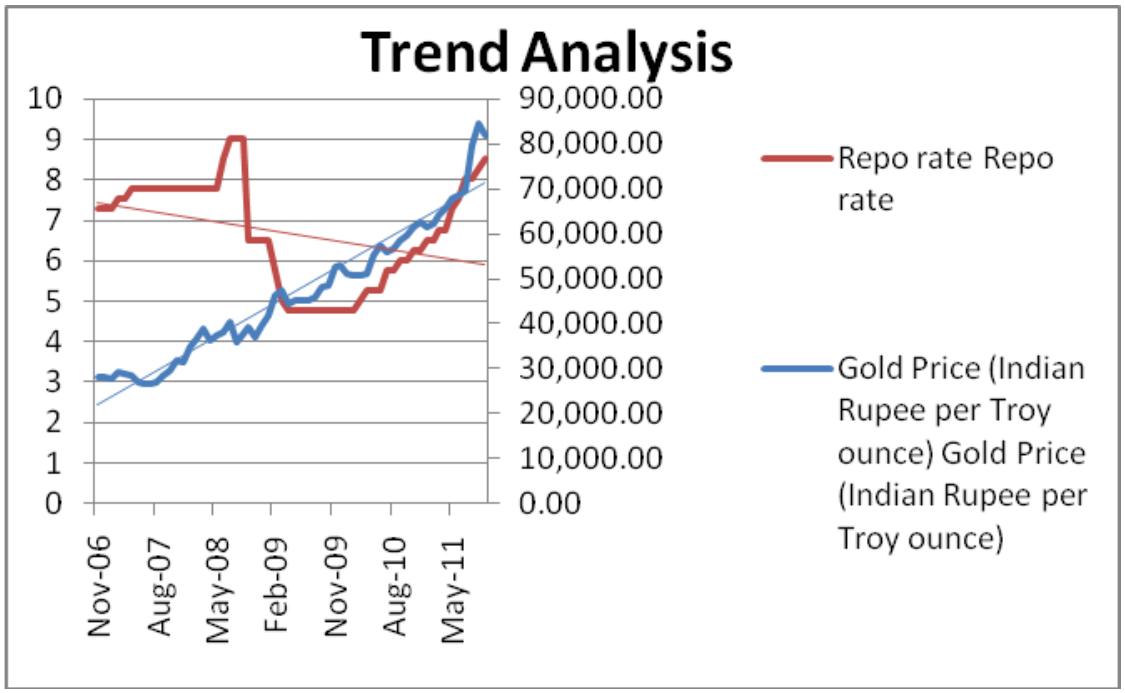

Hypothesis Assumed : $\left(\mathbf{H}_{\mathbf{0}}\right)$-. The Repo rate doesn't affect the gold prices.

*NOTE- By analyzing the graph and table it can be said that there are three periods.

First one being the period where there is no drastic increase in the repo rates.(November-06 to August-08).

- Second is that period in which there is increase in gold prices but there is decrease in repo rate(September08 to February-10).

- Last is that period in which there is increase in repo rate and gold prices (March-10 to October-11). So it will be better that it is shown in the regression analysis separately in three different parts. The common thing in the 3 parts is that there is continuous increase in gold prices.

Analysis overview:

Regression Analysis for case-1:

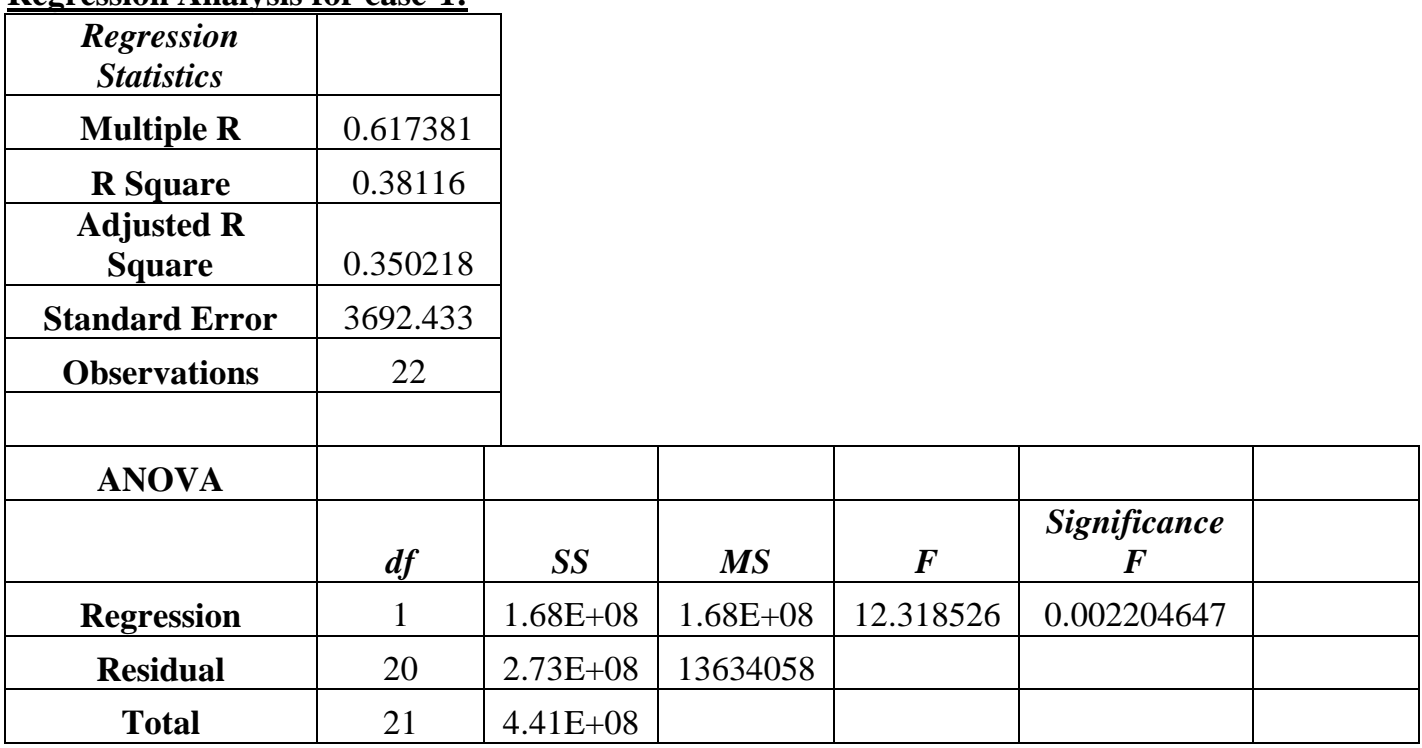

\begin{tabular}{|c|c|c|c|c|c|c|c|c|}
\hline & $\begin{array}{c}\text { Coefficient } \\
s\end{array}$ & $\begin{array}{c}\text { Standard } \\
\text { Error }\end{array}$ & $t$ Stat & $P$-value & Lower $95 \%$ & $\begin{array}{c}\text { Upper } \\
95 \%\end{array}$ & $\begin{array}{l}\text { Lower } \\
95.0 \%\end{array}$ & $\begin{array}{l}\text { Upper } \\
95.0 \%\end{array}$ \\
\hline $\begin{array}{c}\text { Intercep } \\
\mathbf{t}\end{array}$ & -15916.127 & $\begin{array}{c}13624.4259 \\
5\end{array}$ & -1.16821 & $\begin{array}{c}0.256461 \\
5\end{array}$ & $\begin{array}{c}- \\
44336.1814 \\
8\end{array}$ & $\begin{array}{c}12503.92 \\
7\end{array}$ & $\begin{array}{c}- \\
44336.181 \\
5\end{array}$ & $\begin{array}{c}12503.927 \\
4\end{array}$ \\
\hline $\begin{array}{c}\mathbf{X} \\
\text { Variable } \\
1\end{array}$ & 6115.01237 & $\begin{array}{c}1742.28005 \\
3\end{array}$ & $\begin{array}{c}3.50977 \\
6\end{array}$ & $\begin{array}{c}0.002204 \\
6\end{array}$ & $\begin{array}{c}2480.67987 \\
7\end{array}$ & $\begin{array}{c}9749.344 \\
9\end{array}$ & $\begin{array}{c}2480.6798 \\
8\end{array}$ & $\begin{array}{c}9749.3448 \\
7\end{array}$ \\
\hline
\end{tabular}

\section{Regression Analysis for case -2:}




\begin{tabular}{|c|c|}
\hline \multicolumn{2}{|c|}{ Regression Statistics } \\
\hline Multiple R & 0.77424 \\
\hline R Square & 0.599448 \\
\hline $\begin{array}{c}\text { Adjusted R } \\
\text { Square }\end{array}$ & 0.574414 \\
\hline Standard Error & 3169.868 \\
\hline Observations & 18 \\
\hline
\end{tabular}

ANOVA
\begin{tabular}{|c|c|c|c|c|c|}
\hline & $d \boldsymbol{f}$ & $\boldsymbol{S S}$ & $\boldsymbol{M S}$ & $\boldsymbol{F}$ & Significance $\boldsymbol{F}$ \\
\hline Regression & 1 & $2.41 \mathrm{E}+08$ & $2.41 \mathrm{E}+08$ & 23.94491 & 0.000162 \\
\hline Residual & 16 & $1.61 \mathrm{E}+08$ & 10048062 & & \\
\hline Total & 17 & $4.01 \mathrm{E}+08$ & & & \\
\hline
\end{tabular}

\begin{tabular}{|c|c|c|c|c|c|c|c|c|}
\hline & Coefficients & $\begin{array}{c}\text { Standard } \\
\text { Error }\end{array}$ & $\boldsymbol{t}$ Stat & P-value & $\begin{array}{c}\text { Lower } \\
\mathbf{9 5 \%}\end{array}$ & $\begin{array}{c}\text { Upper } \\
\mathbf{9 5 \%}\end{array}$ & $\begin{array}{c}\text { Lower } \\
\mathbf{9 5 . 0 \%}\end{array}$ & $\begin{array}{c}\text { Upper } \\
\mathbf{9 5 . 0 \%}\end{array}$ \\
\hline Intercept & 63298.67 & 3698.964 & 17.11254 & $1.04 \mathrm{E}-11$ & 55457.22 & 71140.13 & 55457.22 & 71140.13 \\
\hline $\begin{array}{c}\mathbf{X} \\
\text { Variable } \\
\mathbf{l}\end{array}$ & & & & & & & & \\
& & & & & & & & \\
\hline
\end{tabular}

Regression Analysis for case-3:

\begin{tabular}{|c|c|}
\hline \multicolumn{2}{|c|}{ Regression Statistics } \\
\hline Multiple R & 0.955556 \\
\hline R Square & 0.913087 \\
\hline $\begin{array}{c}\text { Adjusted R } \\
\text { Square }\end{array}$ & 0.908258 \\
\hline Standard Error & 2873.573 \\
\hline Observations & 20 \\
\hline
\end{tabular}

ANOVA
\begin{tabular}{|c|c|c|c|c|c|}
\hline & $d \boldsymbol{f}$ & $\boldsymbol{S S}$ & $\boldsymbol{M S}$ & $\boldsymbol{F}$ & Significance $\boldsymbol{F}$ \\
\hline Regression & 1 & $1.56 \mathrm{E}+09$ & $1.56 \mathrm{E}+09$ & 189.1031 & $5.47 \mathrm{E}-11$ \\
\hline Residual & 18 & $1.49 \mathrm{E}+08$ & 8257420 & & \\
\hline Total & 19 & $1.71 \mathrm{E}+09$ & & & \\
\hline
\end{tabular}

\begin{tabular}{|c|c|c|c|c|c|c|c|c|}
\hline & Coefficients & $\begin{array}{c}\text { Standard } \\
\text { Error }\end{array}$ & $\mathbf{t}$ Stat & P-value & $\begin{array}{c}\text { Lower } \\
\mathbf{9 5 \%}\end{array}$ & $\begin{array}{c}\text { Upper } \\
\mathbf{9 5 \%}\end{array}$ & $\begin{array}{c}\text { Lower } \\
\mathbf{9 5 . 0 \%}\end{array}$ & $\begin{array}{c}\text { Upper } \\
\mathbf{9 5 . 0 \%}\end{array}$ \\
\hline Intercept & 8577.991 & 4064.57 & 2.11043 & 0.049076 & 38.64677 & 17117.34 & 38.64677 & 17117.34 \\
\hline $\begin{array}{c}\mathbf{X} \\
\text { Variable } \\
\mathbf{1}\end{array}$ & $\mathbf{8 4 4 2 . 2 1 6}$ & 613.9135 & 13.75148 & $5.47 \mathrm{E}-11$ & 7152.432 & 9732.001 & 7152.432 & $\mathbf{9 7 3 2 . 0 0 1}$ \\
\hline
\end{tabular}

As the analysis has been divided into three parts.

Case-1

1. Significant correlation with $\mathrm{r}-0.617381$

Change in repo rate accounts $38 \%$ for the change in gold prices.

Significant linear regression with $\mathrm{p}$ value- 0.0022046

Regression Equation- $\mathrm{Y}=6115.01237 \mathrm{X}-15916.127$

Case-2

2) Significant correlation with $r-0.77424$

Change in repo rate accounts 59\% for the change in gold prices. 
Significant linear regression with $\mathrm{p}$ value- 0.000162

Regression Equation- $\mathrm{Y}=-3256.03 \mathrm{X}+63298.67$

Case-3

3)Significant correlation with $r-0.955556$

Change in repo rate accounts $91 \%$ for the change in gold prices.

Significant linear regression with $\mathrm{p}$ value- 5.47E-11( approx 0).

Regression Equation- Y= 8442.216X+8577.991

From all the three cases it can seen that there is significant correlation between the repo rates and the gold prices $\left(R_{1}-0.61, R_{2}-0.77, R_{3}-0.95\right)$. All the three values are above 0.5 which prove that there is significant correlation. Also the $t$ and $p$ values show that the hypothesis is accepted that repo rates give by the RBI do affect the gold prices.

It can be easily observe that in the period (which relates to sep-08 to oct-08) there is a sharp downfall in the repo rate which is affect of crisis in the economy and inflation rate downfall in this period. So it can be said that there is a high correlation between repo rate and gold prices, being other economic factors constant.

Also by observing the $\mathrm{R}$ square values i.e. $0.39,0.59,0.91$ which tell us that repo rates affect the gold prices in three cases given above. The t-values are 3.509776, -4.89335 and 13.75148 which shows the acceptance of hypothesis. The negative sign only shows the inverse correlation within that period.

\section{INFLATION RATE:}

Gold has always been considered a good hedge against inflation. Rising inflation rates typically appreciates gold prices. Traditional theory implies that the relative price of consumer goods and of such real assets as land and gold should not be permanently affected by the rate of inflation. A change in the general rate of inflation should, in equilibrium, cause an equal change in the rate of inflation for each asset price While calculating the price of gold there are two inflation rates. One is Gold internal inflation rate, which is change in its production from its mines. Other is monetary inflation. The price of gold over the medium to long term is determined by its inflation rate relative to that of the currency you want to measure it with. With most fiat currency inflation rates, running substantially higher than gold's inflation rate it is easy to see why the gold price will continue to increase over time, and why it has consistently increased over time. This is not about to change regardless of short-term volatility.

Graph 6: Trend analysis of Inflation rates and Gold Prices:

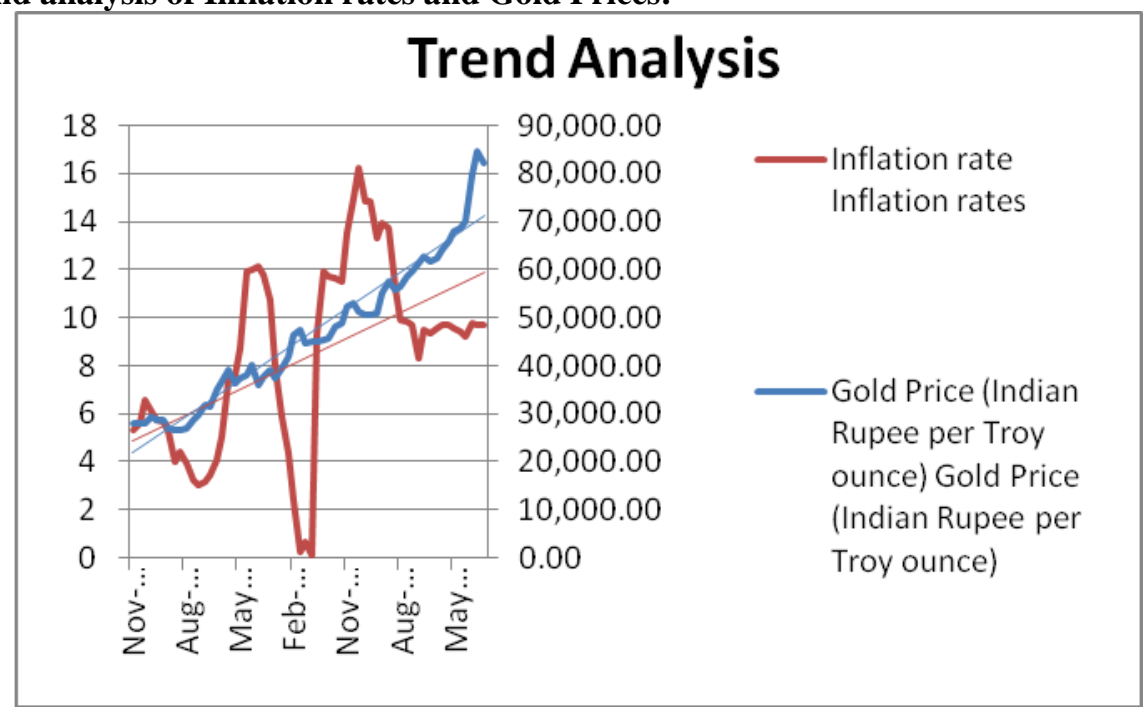

Analysis Overview:

\begin{tabular}{|c|c|}
\hline \multicolumn{2}{|c|}{ Regression Statistics } \\
\hline Multiple R & 0.462288 \\
\hline R Square & 0.21371 \\
\hline $\begin{array}{c}\text { Adjusted R } \\
\text { Square }\end{array}$ & 0.200153 \\
\hline $\begin{array}{c}\text { Standard } \\
\text { Error }\end{array}$ & 13413 \\
\hline Observations & 60 \\
\hline
\end{tabular}

ANOVA 


\begin{tabular}{|l|c|c|c|c|c|}
\hline & $\boldsymbol{d f}$ & $\boldsymbol{S S}$ & $\boldsymbol{M S}$ & $\boldsymbol{F}$ & $\begin{array}{c}\text { Significance } \\
\boldsymbol{F}\end{array}$ \\
\hline Regression & 1 & $2.84 \mathrm{E}+09$ & $2.84 \mathrm{E}+09$ & 15.76414 & 0.0002 \\
\hline Residual & 58 & $1.04 \mathrm{E}+10$ & $1.8 \mathrm{E}+08$ & & \\
\hline Total & 59 & $1.33 \mathrm{E}+10$ & & & \\
\hline
\end{tabular}

\begin{tabular}{|c|c|c|c|c|c|c|c|c|}
\hline & Coefficients & $\begin{array}{c}\text { Standard } \\
\text { Error }\end{array}$ & t Stat & P-value & $\begin{array}{c}\text { Lower } \\
\mathbf{9 5 \%}\end{array}$ & $\begin{array}{c}\text { Upper } \\
\mathbf{9 5 \%}\end{array}$ & $\begin{array}{c}\text { Lower } \\
\mathbf{9 5 . 0 \%}\end{array}$ & $\begin{array}{c}\text { Upper } \\
\mathbf{9 5 . 0 \%}\end{array}$ \\
\hline Intercept & 31849.31 & 4097.988 & 7.771938 & $1.48 \mathrm{E}-10$ & 23646.29 & 40052.32 & 23646.29 & 40052.32 \\
\hline $\begin{array}{c}\mathbf{X} \\
\text { Variable } \\
\mathbf{l}\end{array}$ & & & & & & & & \\
\hline
\end{tabular}

Tabulated z-value:3.71

Significant correlation with $\mathrm{r}-0.462288$

Change in repo rate accounts $21 \%$ for the change in gold prices.

Significant linear regression with p value- 0.0002

Regression Equation- $\mathrm{Y}=1754.174 \mathrm{X}+31849.31$

The value of multiple $\mathrm{R}$ shows that (0.46) shows that there is significant relation between gold prices and inflation rate. It verifies whatever our studies are until now that is the gold is an inflation hedge. This analysis also shows that change in inflation rate accounts $21 \%$ for the variation in gold prices variation in gold prices but this movement is in reverse direction.. In addition, it should be noted that increase in inflation rate accounts for increase in investment in gold, as it is an inflation hedge.

Also from the t-value it can be said that the hypothesis assumed can be rejected.. T-value is 3.97 which are greater than tabulated value 3.71. Also in the later period the gap between gold prices and inflation rate becomes larger which shows the inverse movement between them.

Now actually what happens is, when there is increase in inflation rate, generally the RBI increases the CRR and Repo rate and the securities are demanded more. Gold is one of them universally accepted within the accepted within the banking industry. Therefore the demand increases as well as prices also.

$\mathrm{V}$ :FINDINGS and CONCLUSIONS :

1) Hypothesis Assumed $\left(\mathbf{H}_{\mathbf{0}}\right)$ : Gold Prices do not depend upon Dollar exchange rate.

But from $t$ value (-4.136337) which is more than the tabulated value (3.856547) it can predict that there is a relation between US $\$$ and gold prices and the hypothesis assumed is rejected. The negative intercept of t value as well as negative intercept of regression equation shows the inverse relation between the US\$ and gold prices.

2) Hypothesis Assumed $\left(\mathbf{H}_{0}\right)$ : Gold prices do not depend on crude oil prices.

Also the $t$ value is (4.63) greater than the tabulated value (4.25) which shows that the Hypothesis assumed is rejected. Therefore it can be said that the crude oil prices do affect the prices of gold significantly.

3) Hypothesis Assumed : ( Ho). The Repo rate does affect the gold prices.

This part has been again sub-divided into three parts as there were huge fluctuations in repo rates during the period considered. The analysis of the three parts is as follows:

In all the three cases in data analysis, the R_square values i.e. 0.39, 0.59, 0.91 indicate that repo rates do affect the gold prices. Also all the t-values are $3.509776,-4.89335$ and 13.75148 show the acceptance of alternate hypothesis. Negative sign only shows the inverse correlation within that period.

4) Hypothesis Assumed : ( Ho) - The Inflation rate doesn't affect the gold prices.

By observing the t-value it is concluded that the hypothesis assumed is rejected i.e. alternate hypothesis is accepted (T-value is 3.97 which is greater than tabulated value 3.71) and therefore Gold prices do depend upon inflation rates.

\section{Conclusions:}

In India, gold is one of the foundation assets for Indian households in the form of investment. It is viewed as secure, liquid investment.

Four factors have been considered here which influence the gold prices and the analysis of these factors reveals that:

- Gold price and Dollar value share an inverse relationship i.e. an increase in gold price will result in decrease in the Dollar value.

- Gold prices and Crude oil price share a positive correlation which can be understood from the analysis. It can be inferred that an increase in the gold prices will increase the crude oil prices. 
- Gold prices and repo rates are interdependent and also negatively correlated during september-08 to February-10 i.e. increase in repo rates resulted in decrease gold prices and. But the correlation remained positive during the other two periods i.e. from November-06 to August-08 and March-10 to october-11.

- Gold prices and inflation rates are also dependent and positively correlated i.e. increase in inflation increases gold prices also.

From the study it is concluded that all the select factors like USD, crude oil prices, repo rate and inflation do have impact on the price of the gold as given in detail their relationship eith price of the gold in the conclusions part above.

\section{References}

[1] Adrangi, B., Chatrath, A., Raffiee, K.,2003, Economic activity, inflation and hedging: The case of gold and silver investments, The Journal of Wealth Management 6, 60-77.

[2] Blose, L.E., 2010, gold prices, cost of carry, and expected inflation, Journal of Economics and Business 62, 35-47.

[3] Capie, F., Terence, C.M., Wood, G., 2005, Gold as a hedge against the dollar, International Financial Markets, Institution and Money 15, 343-352.

[4] Devdutt Pattanaik (2010): "Sacred Gold", World Gold Council, November, 12-15.

[5] Kannan,R., (2010), An Econometric Analysis, World Gold Council,Pg-16-27.

[6] Larsen, A.B., McQueen,G.R., 1995, REITs, real estate and inflation: Lessons from the gold market, Journal of Real Estate Finance and Economics 10, 285-297.

[7] Moore,G.H.,1990, gold prices and a leading index of inflation, Challenge33, 52-56.

[8] Orawan Ratanapakorn and Subhash C. Sharma (2007), Dynamic Analysis between the US Stock Returns and the Macroeconomic Variables, Applied Financial Economics, 17(4-6), 369-377.

[9] Perry Sadorsky (1999), Oil price shocks and stock market activity, Energy Economics,21(5),449-469.

[10] Sashikant Singh (2012): "Gilt Edged paper", Dalal Street - Investment Journal, Vol.27.No.2,15 January 2012, 74-75.

[11] Sherman, E.J.,1983, A gold pricing model, Journal of Portfolio Management 9, 68-70.

[12] WGC (2010),World Gold Council. The 10-year gold bull market in perspective, World GoldCouncil,5-7

Websites:

- www.rbi.org.in

- WWW.goldresearch.org.in

- www.gold.org

- www.investopedia.com

- www.bseindia.com

- www.moneycontrol.com

- www.mcxindia.com

- www.kitco.com

- www.karvy.com

- www.rateinflation.com 